Стронина и о выдачи ему единовременного пособия. -5 с.

УдК: $378.013+315.6+351.8$

Ірина Ткачук

\title{
СУТНІСТЬ І СТРУКТУРА ФЕНОМЕНУ «ІНТЕРПРЕТАЦІЙНА КОМПЕТЕНТНІСТЬ СТУДЕНТІВ ПЕДАГОГІЧНОГО КОЛЕДЖУ»
}

Ткачук I. О. Сутність і структура феномену «інтерпретаційна компетентність студентів педагогічного коледжу».

У статті розглянуто поняття «інтерпретаційна діяльність», «інтерпретаційна компетентність»; розкрито сутність i структуру феномену «інтерпретаційна компетентність студентів педагогічного коледжу». Визначено, що структура інтерпретаційної компетентності студентів педагогічного коледжу містить аксіологічний, когнітивний, діяльнісно-творчий та рефлексивний складники з певними показниками.

Ключові слова:інтерпретаційна діяльність, інтерпретаційна компетентність, складники інтерпретаційної компетентності майбутніх учителів.

Ткачук И. А. Сущность и структура феномена «интерпретационная компетентность студентов педагогического колледжа».

В статье рассмотрены понятия «интерпретационная деятельность», «интерпретационная компетентность»; раскрыты сущность и структура феномена «интерпретационная компетентность студентов педагогического колледжа». Определено, что структура интерпретационной компетентности студентов педагогического колледжа содержит аксиологическую, когнитивную, деятельностнотворческую и рефлексивную составляющие с определенными показателями.

Ключевые слова:интерпретационная деятельность, интерпретационная компетентность, составляющие интерпретационной компетентностибудущих учителей.

Tkachuk I. O. Essence and structure of the phenomenon of «interpretational competence pedagogical college students».

The article deals with such notions as «interpretative activity», «interpretative competence»; discloses the nature and structure of the phenomenon of «interpretative competence of students of pedagogical college». It is defined that the structure of interpretative competence of students of pedagogical college contains axiological, cognitive, activity-creative and reflective components with specific characteristics.

Key words:interpretative activity, interpretative competence, components of future teachers' interpretative competence.

В умовах сьогодення значної актуальності набуває проблема формування інтерпретаційної компетентності майбутніх учителів, оскільки спрямованість на розуміння багатоаспектності та багатомірності наукових знань i педагогічних процесів розширює функції професійної діяльності вчителя. Це виявляється в уміннях поширювати контексти засвоєння педагогічних знань, діяти в умовах свободи вибору змісту та форм освіти, самостійно організовувати свою навчальну діяльність $i$, отже, не просто практично володіти навчальними діями, але й рефлексивно, усвідомлюючи сутність і підгрунтя виконуваних дій, оцінюючи їх відповідність цілям та умовам діяльності і визначаючи на цій підставі найбільш ефективні способи інтерпретації знань.

У педагогічних дослідженнях можна виокремити такі напрями наукового Педагогіка вищої та середної школи. - 2014. - Вип. 41 
пошуку з означеної проблеми: визначення закономірностей професійного зростання педагога через дослідження результативності його інтерпретаційної діяльності (М. Гусаковський, О. Ляшенко, О. Олексюк та ін.), вивчення особистості інтерпретатора (А. Брудний, Л. Виготський, I. Демакова, О. Костюк та ін.); взаємопов'язане вивчення особистісного та професійного зростання педагога на основі творчого відтворення інтерпретаційної діяльності (В. Загвязинський, Є. Куришев, І. Раченко, О. Рудницька та ін.).

Компоненти поняття інтерпретаційної компетенції як частини професійної компетентності майбутніх бакалаврів лінгвістики розглядала І. Бороздіна; проблему формування інтерпретаційної компетентності майбутніх інженерів пожежної безпеки досліджував Д. Бучельников; формування інтерпретаційної компетентності старшокласників у процесі вивчення зарубіжної літератури було предметом дослідження О. Ратушняк. Натомість, проблема формування інтерпретаційної компетентності студентів педагогічного коледжу не була предметом окремого наукового дослідження.

Mema cmammi полягає у визначенні сутності i структури феномену «інтерпретаційна компетентність студентів педагогічного коледжу».

Витоки актуальності проблеми інтерпретації в педагогічному процесі полягають насамперед у поєднанні суто педагогічних поглядів і завдань із психологічними (теорія особистісного розвитку) та філософськими (герменевтичні концепції інтерпретації) підходами. Інтерпретаційну діяльність в аспекті дослідження ми визначаємо як творчу взаємодію особистостей викладача і студентів, що грунтується на діалозі між ними і має за мету опанування й тлумачення змістовності педагогічних явищ, основною властивістю якого є поліваріантність розуміння.

На нашу думку, інтерпретаційна діяльність учителя здійснюється в кілька етапів: 1) аналіз ситуації і визначення ступеня іiї складності; 2) розгляд варіантів розв'язання проблеми; 3) визначення найбільш оптимального способу розв'язання ситуації, що виникла; 4) постановка перед учасниками ситуації завдань для іiї розв'язання; 5) оцінка і корекція власних дій та дій учнів чи їхніх батьків.

Безумовно, виконання інтерпретаційної діяльності передбачає сформованість у студентів педагогічного коледжу інтерпретаційної компетентності, яку ми розглядаємо як інтегративне особистісне утворення, що характеризується високим рівнем володіння психолого-педагогічними i фаховими знаннями, розвиненими творчими вміннями, визначається рівнем сформованості ціннісно-смислових орієнтацій особистості, здатної мобілізувати отримані знання, уміння та досвід інтерпретації в конкретній ситуації, а сам процес формування $є$ рефлексійним осягненням зв'язку між логіко-пізнавальними та ціннісно-смисловими характеристиками навчальної діяльності. У структурі інтерпретаційної компетентності студентів педагогічного коледжу нами виокремлено аксіологічний, когнітивний, діяльнісно-творчий та рефлексивний складники.

Виокремлення аксіологічного складника у структурі інтерпретаційної компетентності студентів педагогічного коледжу зумовлений тим, що інтерпретація пов'язана 3 проблемою цінностей. На нашу думку, сам факт інтерпретації вже свідчить про цінність об'єкта, що інтерпретується. По-друге, як підкреслює О. Іщенко, «інтерпретація пов'язана з оцінкою, яка завжди явно чи неявно присутня в ній» $[4$, с. 70]. Дослідниками інтерпретація розглядається як елемент розумової культури інтерпретування (О. Котляревська), як результат особливої духовної діяльності свідомості, яку визначають як своєрідне переведення не тільки в іншу систему мови (знаково-символічну), а й іншу систему мислення, необхідну для розуміння двоїстої природи предмета інтерпретації. 
Зазначимо, що, по-перше, встановлення співвідношення між інтерпретацією й особистісними характеристиками є лише одним зі шляхів рішення питанняпро особливості і детермінацію інтерпретаційного процесу, по-друге, ціннісно-смисловий аспект інтерпретації розкриває зміст формування цінностей, спрямованих на семантичне дослідження, яке акцентує увагу на смисл знакових систем. Показниками аксіологічного складника $є$ мотивація студентів на здійснення інтерпретаційної діяльності і розвиток емпатії. Саме ці показники, на нашу думку, характеризують ціннісне ставлення майбутніх учителів до своєї майбутньої професійної діяльності та сприйняття інших людей (школярів, їхніх батьків, колег тощо) як найвищої цінності.

Наступним складником інтерпретаційної компетентності майбутніх учителів визначено когнітивний складник, оскільки не маючи знань щодо інтерпретації, інтерпретаційної діяльності та ऑiі ролі в педагогічній професії, не вміючи інтерпретувати навчального матеріалу, вони не зможуть на високому професійному рівні здійснювати інтерпретаційну діяльність.

Ми згодні з Л. Кацовою, що студентів насамперед слід ознайомити 3 понятійним апаратом і надати систему знань, необхідних для виконання завдань майбутньої діяльності, при цьому забезпечити розвиток розумових якостей, операцій і процесів, видів і форм мислення відповідно до специфіки завдань і умов професійної діяльності, оскільки чим більш багате i розвинене професійне мислення, тим сильніший уплив його на професійний інтерес [6].

Спираючись на технологічний аналіз педагогічної діяльності з погляду ії об'єкта, цілей, завдань, умов, засобів і результатів, А. Закірова розглядає логічні форми предмета інтерпретації. Так, науковець підкреслює, що формування логікогносеологічного аспекту предмета інтерпретації успішно здійснюється на матеріалі наукового навчально-методичного тексту. Результативність такої діяльності, на думку дослідника, забезпечують такі якості особистості вчителя, як-от: уміння знаходити в навчальному тексті головний елемент, уміння концентрувати увагу та розумову активність, уміння формулювати наукові та навчальні проблеми, розвинена потреба віднайти джерело проблеми, зрозуміти іiі суть, уміння встановлювати структурні зв'язки між елементами наукових знань, уміння проникати в суперечливу сутність явищ, що осягаються [3]. При цьому раціональне начало в інтерпретації проблеми переважає, що сприяє упорядкуванню й систематизації уявлень про педагогічні факти і явища. 3 огляду на вищезазначене, показниками когнітивного складника у структурі інтерпретаційної компетентності нами визначено обізнаність студентів педагогічного коледжу про інтерпретаційну діяльність і вміння інтерпретувати навчальний матеріал.

Наступним складником у структурі інтерпретаційної компетентності студентів педагогічного коледжу $є$ діяльнісно-творчий. Зауважимо, що інтерпретаційна діяльність у своїй основі передбачає творчість. Зазначене підтверджується трактуванням творчості науковцями, які розглядають іiі, яквідкриття невідомого, створення нового, подолання стереотипів та шаблонів (А. Брушлинський), як створення нового (Л. Виготський). Ми поділяємо думку Я. Пономарьова, який наголошує на тому, що для особистості, яка прагне до творчості, характерними є оригінальність, ініціативність, висока самоорганізація, велика працездатність [9].

Розглядаючи ціннісно-смисловий аспект інтерпретації, науковці (В. Андросюк, М. Бахтін, Ю. Борев, Є. Гуренко, Н. Коріхалова, О. Рудницька та ін.) підкреслюють, що формування особистісного смислу 3 використанням інтерпретаційних прийомів обов'язково передбачає самопізнання, рефлексію, творче домислювання творів мистецтва. У контексті нашого дослідження особистісний смисл навчального 
матеріалу виникає у процесі творчого переосмислення дидактичної проблеми, коли один $\mathrm{i}$ той самий навчальний зміст надається різнимивихідними логічними структурами. Студент навчається, обираючи шлях творчості, не припиняючи пошуків можливих засобів розуміння та відтворення змісту дидактичного модуля за допомогою графічного, послідовного та парного надання вихідних логічних структур, порівнюючи різноманітні варіанти навчального змісту, намагаючись надати йому символічного вигляду. У процесі такого творчого розуміння «педагогічна майстерність набуває смислової основи і стає зовнішнім виявом, засобом реалізації внутрішнього суб'єктного світу студента» [1, с. 136].

Важливим показником діяльнісно-творчого складника інтерпретаційної компетентності, на нашу думку, є комунікативні вміння. В. Кан-Калик зазначає, що для реалізації цілісного педагогічного процесу необхідними є: вміння педагога спілкуватись на людях; уміння цілеспрямовано організовувати спілкування й управляти ним; уміння швидко, оперативно та правильно орієнтуватися в умовах спілкування, що змінюються; правильно планувати та здійснювати систему комунікації, зокрема, іiі важливу ланку - мовленнєвий вплив; швидко й точно знаходити адекватні змісту акту спілкування комунікативні засоби, які одночасно відповідають творчій індивідуальності педагога та ситуації спілкування, а також індивідуальним особливостям вихованця; вміння постійно відчувати й підтримувати зворотний зв'язок у спілкуванні. На його думку, зазначені групи комунікативних умінь у своєму складі містять також інші вміння, а саме: встановлення психологічного контакту, завоювання ініціативи та організацію «пристосувань»; сприймання й розуміння людини людиною; використання жестів [5].

Останнім складником нами визначено рефлексивний. Рефлексія визначається як здатність учителя до самоаналізу. Самоаналіз, як зауважує Н. Корепанова, і 3 цим важко не погодитися, є засобом успішної взаємодії і взаєморозуміння вчителя 3 учнями, батьками, колегами. У зв'язку з цим акцент переноситься на способи та прийоми здійснення аналізу, в якому особливе місце відводиться усвідомленню засобів і методів вимірів кінцевих результатів. Тому аналіз власної діяльності можна розглядати як цілеспрямований процес установлення відношень між діями, мотивами та засобами чи вихід у зовнішню позицію одного суб'єкта діяльності відносно діяльності іншого [7, с. 66].

Відтак, самоаналіз можна розглядати як переосмислення вчителем своєї діяльності. Цей процес відображає проблемно-конфліктні ситуації і породжує дієве ставлення педагога як цілісного «Я» до власної поведінки та спілкування, до здійснюваної діяльності, соціокультурного відбиття.

У процесі усвідомлення норм, правил, моделі своєї професії (вимог до педагогічної діяльності та спілкування, до особистості) як еталонів для усвідомлення своїх якостей, зазначає О. Кузнецова, у студентів- майбутніх учителів виникає потреба у професійно-орієнтованій рефлексії. Якщо студент не ознайомлений 3 тим, яким він повинен бути, як йому бажано будувати свої стосунки з учнями, колегами, батьками, то йому важко оцінити й себе [8].

Наявність педагогічної рефлексії О. Власова пропонує визначати за такими ознаками: глибина, проблемність та критичність мислення; відкритість, готовність до діалогу, толерантність до чужої думки, чуйність до іншої людини; гнучкість у пошуку альтернативних підходів до розв'язання проблеми; варіативність та пластичність у комунікативних стратегіях; особистісне включення в діяльність, прийняття відповідальності за вибір рішення [2]. 
Відтак, рефлексивний складник є необхідним у структурі інтерпретаційної компетентності студентів педагогічного коледжу, показниками якої нами визначено вміння інтерпретувати й аналізувати свою діяльність і діяльність довколишніх людей та вміння інтерпретувати й аналізувати діяльність молодших школярів.

Важливою професійною якістю сучасного вчителя $\epsilon$ його інтерпретаційна компетентність, що допомагає вдосконалювати навчально-виховний процес, грунтуючись на педагогіці розуміння. Набуття майбутніми вчителями початкової школи знань щодо інтерпретаційної компетентності, оволодіння ними необхідними вміннями й навичками інтерпретаційної діяльності буде відбуватись ефективно, якщо в навчально-виховний процес педагогічних коледжів будуть упроваджені відповідні педагогічні умови, що становить перспективу наших подальших досліджень.

\section{Література}

1. Бондаревська Е. В. Парадигмальний підхід до розробки змісту ключових педагогічних компетенцій / Е. В. Бондаревська, С. В. Кульневич // Педагогіка. 2004. - № 10. - С. 23-31. 2. Власова О. І. Педагогічна психологія:[навч. посібник] / О. І. Власова. - К., 2005. - 315 с. 3. Закирова А. Ф. Теоретические основы педагогической герменевтики: [монография] / А. Ф. Закирова. - Тюмень : Изд-во Тюменского гос. ун-та, 2001. - 152 с. 4. Ищенко Е. Н. Новая парадигма интерпретации в дискурсивном поле современной философии / Е. Н. Ищенко // Вестник МГУ. Серия 7 Философия. - 2004. - № 6. - С. 62-74. 5. Кан-Калик В. А. Педагогическая деятельность как творческий процесс / В. А. Кан-Калик. -М., 1976. 286 с. 6. Кацова Л. І. Формування професійного інтересу у майбутніх учителів у процесі педагогічної практики: автореф. дис. на здобуття наук. ступеня доктора пед. наук: спеціальність 13.00.04 «Теорія та методика професійної освіти» / Л. І. Кацова. Харків, 2005. - 19 с. 7. Корепанова Н. В. Профессионально-личностное становление и развитие педагога / Н. В. Корепанова// Педагогика. - 2003. - № 3. - С. 66-71. 8. Костюк А. Г. Восприятие мелодии. Мелодические параметры процесса восприятия музыки / А. Г. Костюк. - К. : Наукова думка, 1986. - 189 с. 9. Кузнєцова О. А. Потреба у професійно-орієнтованій рефлексії як умова формування самовизначення майбутнього вчителя / О.А.Кузнєцова // Науковий вісник Південноукраїнського державного педагогічного університету імені К. Д. Ушинського: зб. наук. пр. - 2004. № 5-6. - С. 67-74. 10. Пономарев Я. А. Психология творчества: общая, дифференциальная, прикладная / Я. А. Пономарев. - М. : Наука, 1990. - 222 с.

УДК 37.013

Вікторія Хребтова

\section{РОЗВИТОК ІДЕЙ ПОЛІКУЛЬТУРНОГО ВИХОВАННЯ В КОНТЕКСТІ СВІТОВОГО ДОСВІДУ}

Хребтова В. В. Розвиток ідей полікультурного виховання в контексті світового досвіду.

У статті з'ясовується питання про зародження й перспективи розвитку полікультурного виховання, аналізується стан названої проблеми в сучасній педагогіці, характеризується загальнопедагогічне питання сутності полікультурного виховання, визначається специфіка та основні етапи розвитку полікультурного виховання відповідно до нової освітньої парадигми.

Ключові слова: полікультурне виховання, поліетнічне й полікультурне суспільство, культурні цінності, плюралізм культур, мультиідентична особистість.

Хребтова В. В. Развитие идей поликультурного воспитания в контексте Педагогіка вищої та середної иколи. - 2014. - Вип. 41 